\title{
Prevalence of Obesity in Medical students and its correlation with cardiovascular risk factors: Emergency Alarm for Today?
}

\author{
Purohit G, ${ }^{1}$ Shah $\mathrm{T}^{2}{ }^{2}$ Harsoda JM, ${ }^{1}$
}

\author{
Corresponding Author \\ Geetanjali Purohit \\ Department of Physiology \\ SBKS MI \& RC, Dhiraj Hospital \\ Sumandeep Vidyapeeth \\ Piparia, Vadodara 391760, Gujarat, India. \\ E-mail: purohit85geet@gmail.com
}

\section{Citation}

Purohit G, Shah T, Harsoda JM. Prevalence of Obesity in Medical Students and its Correlation with Cardiovascular Risk Factors: Emergency Alarm for Today?. Kathmandu Univ Med J 2015;52(4):341-5.

\section{ABSTRACT}

\section{Background}

It is predicted that the prevalence of overweight and obesity will rise significantly by 2015 in young population. Problem of overweight and obesity has been recognized as public health problem worldwide due to the fact that it increases the risk of chronic diseases such as Cardiovascular Diseases (CVD), stroke, diabetes, sleep apnoea, osteoarthritis etc.

\section{Objective}

To assess the body mass index in medical students and its association with various cardiovascular risk factors like blood pressure, dietary habits, and family history of cardiovascular diseases.

\section{Method}

A university based cross-sectional analytical study was conducted in Department of Physiology, Smt. B.K. Shah Medical Institute \& Research Center, Vadodara, Gujarat. Data was collected through convenient sampling technique by using selfadministered questionnaire followed by anthropometric measurement. Body Mass Index (BMI) of 138 first year medical students was assessed. Systolic blood pressure, diastolic blood pressure, pulse pressure, mean blood pressure, pulse rate and arterial oxygen saturation were measured.

\section{Result}

Data was compiled in excel sheet, analyzed for percentage and proportion. Chi square and Pearson correlation test were also applied and alpha error was set at $5 \%$ level. In comparison to the students with normal BMI, students with $\mathrm{BMI}>25 \mathrm{~kg} / \mathrm{m}^{2}(\mathrm{~N}=49)$ showed significantly high blood pressure indices. Dietary habits and family history of cardiovascular diseases were also noted. Highly significant association of high BMI was found with elevated blood pressure $\left(X^{2}=7.4042^{* * *}, p<0.001\right)$ and presence of family history of cardiovascular diseases $\left.X^{2}=9.8625^{* * *}, p<0.001\right)$. BMI is negatively correlated with $\mathrm{SpO}_{2}(r=-0.0504, p<0.05)$ and pulse rate, while positively correlated with systolic blood pressure $(r=0.2736)$ and diastolic blood pressure $(r=0.0275)$.

\section{Conclusion}

In conclusion, majority (more than 35\%) of medical students were overweight, high prevalence of cardiovascular risk factors like family history, elevated blood pressure and less $\mathrm{SpO}_{2}$.

\section{KEY WORDS}

Body mass index, fast food, oxygen saturation 


\section{INTRODUCTION}

Cardiovascular risk factors can be categorized into independent or non-modifiable risk factors and dependent or modifiable risk factors. Independent risk factors include age, gender and family history. Dependent factors of the 1st grade include smoking, hypertension, lipid disorders and diabetes, while dependent factors of the $2^{\text {nd }}$ grade include overweight, improper dietary habits and stress. ${ }^{1}$ Obesity has been primarily diagnosed by using the BMI for the last 30 years. Based on BMI obesity is divided into different classes; normal weight $\left(18.5-25 \mathrm{~kg} / \mathrm{m}^{2}\right)$, underweight (< $\left.18.5 \mathrm{~kg} / \mathrm{m}^{2}\right)$ and overweight $\left(>25 \mathrm{~kg} / \mathrm{m}^{2}\right){ }^{2}$

In medical profession fast food consumption is one of the major factor reported as one of the cause of obesity in teenagers. The causes which influence the fast food consumption are convenience, cost, menu choices, flavor and taste, ${ }^{3,4}$ but in the real world situation food decision are made within the context of time pressure, specific environment, individual presence and social factors. Obesity is associated with sympathetic activation and is the leading risk factor for development of hypertension. ${ }^{5,6} \mathrm{BMI}$ is a better tool to assess the obesity than other methods with a significant clinical utility. ${ }^{7,8}$ The medical profession is a highly stressful profession and prevalence of obesity and other cardiovascular risk factors are not studied extensively.

In the present study, author was keen to find out the correlation between $\mathrm{BMI}$ and $\mathrm{BP}$ indices viz. systolic blood pressure (SBP), diastolic blood pressure (DBP), pulse pressure (PP), mean blood pressure (MBP), pulse rate and $\mathrm{SpO}_{2}$. We also analyzed family history of CVD, dietary habits of medical students and knowledge about the healthy and unhealthy food.

\section{METHODS}

It was a descriptive cross-sectional study, conducted in Department of Physiology, Smt. B.K. Shah Medical Institute and Research center, Sumandeep Vidyapeeth between the periods of July 2013 to December 2013. Sample size was 138 Medical Students and data was collected through a self-structured questionnaire based on a review of similar studies. The data was collected through a self structured questionnaire. Ethical clearance was obtained from Sumandeep University (SVIEC/ON/MEDI/RP/B121) and written informed consent was obtained from the subjects.

Inclusion: I year MBBS students, apparently healthy, aged between 18-25 years, volunteered for study.

Exclusion: Unhealthy with any clinical condition and those who were taking any medication.

The questionnaire contains several anthropometric data included information of age, height and weight. Height was determined using a length measuring tape in $\mathrm{cm}$ and recorded in the nearest $0.5 \mathrm{~cm}$. Weight was measured using kg weight scale and recorded to the nearest $0.1 \mathrm{~kg}$ using electronic scale. The BMI calculating formula was weight in $\mathrm{kg}$ divided by square of height in meter. BMI was classified in to three groups, Group 1 underweight (BMI $<18.5 \mathrm{~kg} / \mathrm{m}^{2}$ ), Group 2 Normal (BMI 18.5-25 kg/m²), Group 3 overweight $\left(\mathrm{BMI}>25 \mathrm{~kg} / \mathrm{m}^{2}\right)$, which further divided in to two sub groups Grade-1 Preobese is $25-29.9 \mathrm{~kg} / \mathrm{m}^{2}$ and Grade-2 Obese is $30-34.9 \mathrm{~kg} / \mathrm{m}^{2}$. The questionnaire also included sociodemographic data, education level, diet modifications \& food habits, family history of cardiovascular diseases and knowledge about the healthy and unhealthy food. Diet modification was defined as change in food consumption on the basis of the role of that particular food in the development of cardiovascular disease.

Cardio-respiratory parameters were studied include BP indices (SBP, DBP, PP, MBP), pulse rate and arterial oxygen saturation $\left(\mathrm{SpO}_{2}\right)$. Blood pressure was measured by digital BP instrument. In case the two readings differed by over $10 \mathrm{~mm}$ of $\mathrm{Hg}$, a third reading will be obtained, and average of all these measurements had been taken. Blood pressure was classified as normal (SBP $<120$ and DBP $<80$ $\mathrm{mmHg}$ ), pre-hypertension ( $\mathrm{SBP}=120-139$ and/or $\mathrm{DBP}=80$ $89 \mathrm{mmHg}$ ), stage I hypertension (SBP=140-159 and/or $\mathrm{DBP}=90-99 \mathrm{mmHg}$ ), and stage II hypertension (SBP >160 and/or DBP $>100 \mathrm{mmHg}$ ). Radial pulse rate was counted manually and $\mathrm{SpO}_{2}$ by digital pulse oxymeter.

Data was collected and grouped by using Microsoft excel. Descriptive data represented by the percentage. Unpaired students t-test was used to compare the data of normal and high BMI. For correlation of BMI with blood pressure, $\mathrm{SpO}_{2}$ and pulse, Pearson correlation test was used. Association of BMI with blood pressure and heredity was analysed by chi square test. The probability level of $p<0.05$ was set for statistical analysis.

\section{RESULTS}

Results showed that out of 138 students total 125 students (More than 90\%) were taking the fast food. Out of 125 students $58.40 \%$ students agreed that they like the fast food, $34 \%$ students consumed due to non availability of homemade food while remaining consumes due to their life style. More than $60 \%$ students were unaware about the fact that fast food is unhealthy. More than $80 \%$ students were vegetarian and only $15 \%$ students were non vegetarian.

Table 1 showed that 49 (35.50\%) students were of BMI >25. Table 2 showed distribution of all participants according to $\mathrm{BMI}$ and $\mathrm{BP}$ indices, pulse rate, $\mathrm{SpO}_{2}$ and heredity. Data comparison showed that BP indices found significantly high in overweight groups. Prevalence of obesity is $13.04 \%$ and of overweight $22.50 \%$. Total prevalence of elevated blood pressure in medical students in our study was $25.20 \%$. Prevalence of hypertension in overweight is $27.50 \%$ against normotensive $18.30 \%$ ( $p<0.05)$. Prevalence of 
hypertension in family history of CVD was $18.60 \%$ against $13.10 \%$ with Normal BP. $p<0.05)$.

Table 1. Demography data of medical students.

\begin{tabular}{|llll|}
\hline Groups & $\begin{array}{l}\text { Number } \\
\text { (N=138) }\end{array}$ & & (MMI \\
\hline Group 1 (BMI <18.5) & 11 & 7.97 & $17.14 \pm 0.58$ \\
\hline Group 2 (BMI 18.5 to 24.9) & 78 & 56.50 & $20.15 \pm 2.63$ \\
\hline Group 3 Preobese G-1 (BMI 25-29-9) & 31 & 22.50 & $27.05 \pm 1.48$ \\
\hline Group 3 Obese G-2 (BMI 30-34.9) & 18 & 13.04 & $32.28 \pm 2.14$ \\
\hline
\end{tabular}

Table 2. Distribution of all students according to BMI and blood pressure indices, pulse rate, $\mathrm{SPO}_{2}$, family history of CVD and statistical analysis.

\begin{tabular}{|c|c|c|c|c|c|}
\hline & \multirow{2}{*}{$\begin{array}{l}\text { Under } \\
\text { weight } \\
\text { Group } 1 \\
(\mathrm{~N}=11)\end{array}$} & \multirow{2}{*}{$\begin{array}{l}\text { Normal } \\
\text { Group } 2 \\
(\mathrm{~N}=78)\end{array}$} & \multicolumn{2}{|c|}{ Overweight } & \multirow[b]{2}{*}{$\begin{array}{l}\text { Normal } \\
\text { ( } N=78 \text { ) Vs } \\
\text { Overweight } \\
\text { ( } N=49 \text { ) } \\
\text { P value }\end{array}$} \\
\hline & & & $\begin{array}{l}\text { Group } 3 \\
\mathrm{G}-1 \\
(\mathrm{~N}=31)\end{array}$ & $\begin{array}{l}\text { Group } 3 \\
\mathrm{G}-2 \\
(\mathrm{~N}=18)\end{array}$ & \\
\hline $\begin{array}{l}\text { SBP } \\
\text { (mmHg) }\end{array}$ & $122.3 \pm 7.6$ & $119.52 \pm 15.2$ & $130.5 \pm 11.9$ & $128.2 \pm 9.46$ & $0.000231^{* * *}$ \\
\hline $\begin{array}{l}\text { DBP } \\
(\mathrm{mmHg})\end{array}$ & $71.3 \pm 9.53$ & $71.04 \pm 9.03$ & $75.8 \pm 9.52$ & $76.8 \pm 6.27$ & $0.00082 * * *$ \\
\hline $\begin{array}{l}\text { PP } \\
\text { (mmHg) }\end{array}$ & $51 \pm 8.5$ & $48.48 \pm 11.9$ & $54.68 \pm 11.13$ & $48.39 \pm 11.03$ & $0.00009^{* * *}$ \\
\hline $\begin{array}{l}\text { MBP } \\
\text { (mmHg) }\end{array}$ & $88.3 \pm 8.03$ & $87.2 \pm 9.96$ & $94.06 \pm 8.95$ & $92.96 \pm 5.38$ & $0.036386 *$ \\
\hline $\mathrm{SpO}_{2}(\%)$ & $96.3 \pm 2.21$ & $97.8 \pm .83$ & $95.6 \pm 1.09$ & $94.6 \pm 1.09$ & $0.04336 *$ \\
\hline $\begin{array}{l}\text { Pulse (/ } \\
\text { min) }\end{array}$ & $78.7 \pm 14.9$ & $74.9 \pm 14.9$ & $75.29 \pm 10.1$ & $73.2 \pm 11.5$ & 0.454958 NS \\
\hline $\begin{array}{l}\text { Family } \\
\text { History } \\
\text { of CVD } \\
(\%)\end{array}$ & $3(27.30 \%)$ & 25 (32.05\%) & $24(77.40 \%)$ & $14(77.80 \%)$ & - \\
\hline $\begin{array}{l}\mathrm{SBP}=\mathrm{Syst} \\
\mathrm{DBP}=\mathrm{Dia} \\
\mathrm{SPO}_{2}=\mathrm{Ox} \\
\mathrm{NS}=\text { not } \mathrm{s}\end{array}$ & $\begin{array}{l}\text { c blood pre } \\
\text { lic blood p } \\
\text { en saturati } \\
\text { hificant }\end{array}$ & $\begin{array}{l}\text { ure in } \mathrm{mmH} \\
\text { ssure in } \mathrm{mmb} \\
\text { in \%age * } \mathrm{p}\end{array}$ & $15, * * * p<0$ & & \\
\hline
\end{tabular}

Table 3 shows the statistical analysis of correlation and association of $\mathrm{BMI}$ with $\mathrm{BP}, \mathrm{SpO}_{2}$ and Family history of CVD. Pearson correlation shows the positive correlation of $\mathrm{BMI}$ with Blood pressure and negative correlation with $\mathrm{SpO}_{2}$ $(p<0.05)$ and pulse rate. Chi square test shows significant relationship of $\mathrm{BMI}$ with family history of CVD $\left(X^{2}=7.4042\right.$, $p<0.001)$ and elevated blood pressure $\left(X^{2}=9.8625, p<0.001\right)$.

\section{DISCUSSION}

This was a cross sectional descriptive study based on self structured questionnaire, where we assessed BMI in medical students and its relation with cardiovascular risk factors. Obesity continue to increase substantially worldwide, affecting all ages, sexes and races, also becoming serious problem in India despite the widespread presence of under nutrition. ${ }^{2}$ We found in our study that more than $35 \%$ medical students are overweight. Similar studies that calculated BMI of medical students have been
Table 3. Statistical analysis of correlation of BMI and association of different BMI groups with other parameters.

\begin{tabular}{|c|c|c|c|c|c|c|}
\hline \multirow[b]{2}{*}{ Variable } & \multicolumn{2}{|c|}{ BMI } & \multicolumn{4}{|c|}{ BMI Groups } \\
\hline & $\begin{array}{l}\text { Pearson } \\
\text { correlation }\end{array}$ & P value & Variable & $\begin{array}{l}\text { Chi } \\
\text { square }\end{array}$ & DF & P value \\
\hline $\begin{array}{l}\text { SBP } \\
(\mathrm{mmHg})\end{array}$ & 0.2736 & $>0.05$ & $\begin{array}{l}\text { Blood } \\
\text { pressure }\end{array}$ & 7.4042 & 03 & $0.00000 * * *$ \\
\hline $\begin{array}{l}\text { DBP } \\
\text { (mmHg) }\end{array}$ & 0.2754 & $>0.05$ & $\begin{array}{l}\text { Family } \\
\text { History }\end{array}$ & 9.8625 & 03 & $0.000000 * * *$ \\
\hline $\mathrm{SpO}_{2}(\%)$ & -0.5046 & $0.0342 *$ & & & & \\
\hline $\begin{array}{l}\text { Pulse } \\
\text { (/min) }\end{array}$ & -0.05216 & $>0.05$ & & & & \\
\hline
\end{tabular}

conducted in Pakistan, Poland, United Arab Emirates (UAE) and Greece..$^{1,9-11}$

Although this study was on a small scale, interesting results for BMI and fast food consumption were obtained. Fast food consumption by medical students cannot be ignored as our results state that more than $90 \%$ of students are taking in day to day life. Here is convincing evidence that increase in the energy density of the diet by fat or sugar together with concomitant eating behaviors like snacking, binge eating and eating out promote unhealthy weight gain through passive over consumption of energy. ${ }^{12,13}$ Probable hypothesis is that more fast food consumption is associated with more energy intake from non-fast food and fast food sources. ${ }^{14}$ Medical field is a challenging and stressful profession and of the factors contributing to obesity, stress seems to be particularly important as stressful condition leads to irregularity in diet, lack of exercise and addiction, each being considered independent factors leading to obesity. ${ }^{15}$

We found a highly significant association of BMI with blood pressure. Blood pressure can be classified as normal (SBP $<120$ and DBP $<80 \mathrm{mmHg}$ ), pre-hypertension (SBP = 120139 and/or $\mathrm{DBP}=80-89 \mathrm{mmHg}$ ), stage I hypertension $(\mathrm{SBP}=140-159$ and/or $\mathrm{DBP}=90-99 \mathrm{mmHg})$, and stage II hypertension (SBP > 160 and/or DBP > $100 \mathrm{mmHg}$ ) ${ }^{16}$ Grouping the students in two categories: those with normal and those with elevated blood pressure $(\geq 120 / 80$ $\mathrm{mmHg}$ ); we found that prevalence of elevated blood pressure was also high. Obesity is strongly associated with hypertension and cardiovascular disease. The prevalence of hypertension was $32.80 \%$ in the urban population and $14.50 \%$ in the rural population in India and reported risk factors of hypertension are Diabetes, higher BMI values, decreased level of physical activity and increased waist circumference, necessitates intervention at the primary health care level for its prevention. ${ }^{17}$ Several central and peripheral abnormalities that can explain the development or maintenance of high arterial pressure in obesity have been identified, include activation of the sympathetic nervous system and the renin-angiotensin-aldosterone 
system. Obesity is also associated with endothelial dysfunction and renal functional abnormalities that may play a role in the development of hypertension. ${ }^{18}$

Our study exhibited that high BMI is significantly correlated with low $\mathrm{SpO}_{2}$. Total body oxygen consumption is increased as a result of an expanded lean tissue mass as well as the oxidative demands of metabolically active adipose tissues. The association of alveolar hypoventilation with obesity is also well known. ${ }^{19-20}$ The accompanying reviews in this nature insight on obesity confirm the identity of several genes involved in the development of obesity in animal models and describe central neural pathways concerned in the regulation of energy balance. Such genes and neural pathways are likely to be important in the genesis of human obesity but they should not detract from the importance of environmental factors. ${ }^{21}$ Concern grows that the current dramatic rise of obesity among adolescents portends a future wave of increasing cardiovascular disease as these overweight youth reach the adult years.

\section{CONCLUSION}

In conclusion we found that more than $90 \%$ students were taking fast food in their diet and $22.45 \%$ and $9.52 \%$ are found to be pre obese and obese respectively. Majority of medical students had normal BMI, high prevalence of cardiovascular risk factors like family history and elevated blood pressure.
This observation is explained largely by Dietary addition of fast food or stress of medical education. They had substantial knowledge regarding risk factors and measures required to reduce them but little effort is made by them to modify their lifestyle as evident from lack of implementation of healthy diet modification and low physical activity level. It is noticeable, how the current generation of teenage is more towards the consumption of fast food. These changes in population anthropometry is not restricted medical students or to a particular ethnic group, but reflects a major global shift in body size. We suggest that future research about eating behaviors focus on the questions regarding typical consumption of beverages with sugar added, fruits and vegetables, and full portions served at restaurants to further develop a tool for clinical screening.

\section{ACKNOWEDGEMENT}

I acknowledge the ethical committee of Sumandeep Vidyapeeth for their support. I want to thank the $1^{\text {st }}$ MBBS students to cooperate with me in any ways. At last I acknowledge the Dr. Ashish Trivedi from Community Medicine department for their valuable help for statistical analysis of data.

\section{REFERENCES}

1. Poreba R, Gac P, Zawadzki M, Poreba M, Derkacz A, Pawlas K et al. Life style and cardiovascular risk factors among students of Wroclaw postgraduate schools. Pol Arch Med Wewn 2008; 118: 102-10.

2. Ravishanker P, Madanmohan, Udupa K, Prakash S. Correlation between body mass index and blood pressure indices, hand grip strength and handgrip endurance in underweight, normal weight and overweight adolescent. Indian J Physiol Pharmacol 2005;49(4):45561.

3. Driskell JA, Meckna BR, Scales NE. Difference exist in the eating habits of university men and women at fast food restaurants. Nutrition Research. 2006;26(10): 524-30.

4. Brynat R, Dundes L. Fast food perception: A pilot study of college students in Spain and United State. Apetite. 2008;51(2):327-30.

5. Ganong WF. Cardiovascular regulatory mechanisms In: Review of Medical Physiology, (International edition), New York: McGraw Hill. 2003; p. 599-613.

6. Rahmouni K, Correia MLG, Haynes WG, and Mark AL. Obesity associated hypertension. Hypertension. 2005; 45: 9-14.

7. Katzmarzyk PT, Srinivasan SR, Chen W, Malina RM, Bouchard C, and Berenson GS. Body mass index, waist circumference and clustering of cardiovascular disease risk factors in a biracial sample of children and adolescents. Pediatrics. 2004; 114:198-205.
8. Neovius $\mathrm{M}$, Linne $\mathrm{Y}$, Rossner S. BMI, waist-circumference and waisthip-ratio as diagnostic tests for fatness in adolescents. International Journal of Obesity. 2005;29(2):163-9.

9. Sajjad R, Sheikh MA, Hussain MFA. Dietary modification, Body Mass Index (BMI), Blood Pressure (BP) and cardiovascular risk in medical students of a government medical college of Karachi. J Pak Med Assoc. 2010:60(11);970-4.

10. Carter AO, Elzubeir M, Abdulrazzaq YM, Revel AD, Townsend A. Health and lifestyle needs assessment of medical students in the United Arab Emirates. Med Teach. 2003;25:492-6.

11. Bertsias G, Mammas I, Linardakis M, Kafatos A. Overweight and obesity in relation to cardiovascular disease risk factors among medical students in Crete, Greece. BMC Public Health. 2003;3:3.

12. WHO Report of a Joint WHO/FAO Expert Consultation? Diet, Nutrition and the prevention of chronic diseases. WHO Technical Report series. 2003:916.

13. Sinakio AR, Donahue RP, Jacobs DR, Prineas RJ. Relation of weight and rate of increase in weight during childhood and adolescence to body size, blood pressure, fasting insulin, and lipid in young adults. The Minneapolis Children's Blood Pressure Study. Circulation 1999;99:1471-6. 
14. Pereira MA, Kartashov Al, Ebbeling CB. Fast food habits, weight gain, and insulin resistance (the CARDIA study):15-year prospective analysis. Lancet. 2005;365(9453):36-42.

15. Kumar S, Mahabalaraju KD, Anuroopa MS. Prevalence of obesity and its influencing factor among affluent school children of Devanagere City. Indian Journal of Community Medicine. 2007;32:15-7.

16. Margret R, Brian B. High Blood Pressure in Children and Adolescents. Am Fam Physician. 2012;85(7):693-700.

17. Midha T, Idris MZ, Saran RK, Srivastav AK, Singh SK. Prevalence and determinants of hypertension in the urban and rural population of a north Indian district. East Afr J Public Health. 2009 Dec;6(3):268-73.
18. Rahmouni K, Marcelo LG Correia, William GH, Allyn LM. Obesity associated hypertension. Hypertension 2005;45:9-14.

19. Masserli, FH etal. Borderline hypertension and obesity: two prehypertensive states with elevated cardiac output. Circulation 1982;66:55-60.

20. Burwell S, Eugene DR, Whasley RD, Albert GB. Extreme obesity associated with alveolar hypoventilation- A Pickwickian syndrome. The American Journal of Medicine. 1956;21(5):811-8.

21. Peter GK. Obesity as a medical problem. Nature 2000;404(6):635-43. 